\title{
HEADLAND SEDIMENT BYPASSING AND OVERPASSING: EXAMPLES FROM SOUTHERN BRAZIL
}

\author{
ANTONIO H.F. KLEIN ${ }^{1}$, GUILHERME VIEIRA DA SILVA², ANDREW D. SHORT ${ }^{3}$, \\ ELÍRIO E. TOLDO JR. ${ }^{4}$, MAIARA W. PINTO ${ }^{1}$
}

1. Coordenadoria Especial de Oceanografia, Centro de Ciências Físicas e Matemáticas, Universidade Federal de Santa Catarina (UFSC), Campus Universitário - Trindade, Florianópolis, SC - 88040-900, Brasil. antonio.klein@ufsc.br, maiarawp@gmail.com

2. Griffith Centre for Coastal Management, Griffith University, G51 2.07, Gold Coast Campus QLD 4222. g.vieiradasilva@griffith.edu.au

3. School of Geosciences, University of Sydney, NSW, Australia. andrew.short@sydney.edu.au

2. 4. Universidade Federal do Rio Grande do Sul, Centro de Estudos de Geologia Costeira e Oceânica, Av. Bento Goncalves 9500, 91509.900 Porto Alegre, RS. toldo@ufrgs.br

\begin{abstract}
This paper addresses the range of processes (wind, waves, tides and currents) responsible for transporting sediment past headlands by bypassing and overpassing. Field data was used to quantify rates of dune overpassing and headland bypassing. Based on these results a conceptual sediment budget and process model was developed using field data and numerical modelling for the north coast of Santa Catarina Island, Southern Brazil.
\end{abstract}

\section{Introduction}

Transport around headlands (known as headland bypassing and headland dunefield overpassing) has been described by Evans (1943), Tinley (1985), McLachlan et al. (1994), Short and Masselink (1999) and Smith (2001). According to McLachlan et al. (1994) headland overpassing tend to be nonaccretionary in the long term and play an important role in maintaining the sand budget by transport between bays in a headland bay coast. Roy et al. (1999) described accumulations of sand in front of headland as a migrating sandy body. This phenomena occurred in locations where coastal sand is unable to pass around headlands via longshore drift (bypassing) or bypass in the dune systems (overpassing) (McLachlan et al. 1994) so sediment accumulates offshore (Martin and Flemming 1986). These different cells of sediment transport and forms different coastal compartments and compartments boundaries (Davies 
1974; Thom et al. 2018), that can be useful for sediment budget calculations. Recently studies, reported that the size and shape of headland, relations to coastal orientation and the closure depth are the main drives to the sediment bypassing versus the longshore transport (George et al. 2015; Vieira da Silva et al. 2016b, 2018; McCarroll et al. 2018). However, both processes have only recently been investigated in the field and numerically (ex.: Goodwin et al. 2013; Duarte et al. 2014, Ab Razak 2015; Vieira da Silva et al. 2016a,b; Vieira da Silva et al. 2018; Ribeiro et al. 2014; Ribeiro 2017; McCarroll et al. 2018). Regardless of the distinct methods of assessing headland bypassing and overpassing there is still a need for a standard procedure to analyze the process and define the types, because HSB and HSO are important components of regional sediment budget.

Headland sand bypassing (HSB) and overpassing (HSO) are the processes by which the sand is transported from the updrift to the downdrift side of a headland by wave, currents and/or wind. This paper uses field data to quantify the processes (wind, waves, tides and currents) responsible for transporting sediment past headlands by both bypassing and overpassing. A conceptual model of the process is developed using field data and numerical modelling for the north coast of Santa Catarina Island, based in previous studies developed in the study area (Vieira da Silva et al. 2016a, 2016b, 2018; Porpilho 2015; Porpilho et al. 2014, 2015, 2016; Pinto and Klein 2014, Pinto 2015, Pinto et al. 2015, Martns 2017, Martins et al. 2017).

\section{Regional Settings}

The study area is located on the north shore of Santa Catarina Island, southern Brazil, and encompasses seven embayed beaches separated by headlands (Fig. 1). This coast has experienced a sea-level fall of 2-4 m during the last 5-6 ka (Angulo et al. 2006; Hein et al. 2013, 2014, 2015, Cooper et al. 2016, 2018) and the growth of the Jurere Strandplain and Daniela Spit located in the study area trapped $65 \times 10^{6} \mathrm{~m}^{3}$ and $3.6 \times 10^{6} \mathrm{~m}^{3}$ of sand respectively, effectively halting longshore transport for 3000 years; re-initiation of headland bypassing in the last 1000 years allowed for formation of the downdrift $3 \mathrm{~km}$ long Daniela Spit (Hein et al. 2019, in this volume).

The coast is classified as microtidal $(0.4-1.2 \mathrm{~m})$, with an east coast swell wave climate (Hs 1-1,5m), and is a rugged bedrock-controlled coast containing 
embayed strandplains (Klein et al. 2016). The coast is influenced by storm surges that can reach up to $1 \mathrm{~m}$ above astronomical tide levels and winds are predominantly from the NE with stronger south winds associated with the passage of cold-front systems (Klein et al. 2016). It has a Relative Tide Range (RTR) of $\sim 1$ and is predominately a wave-dominated coast (Klein and Menezes 2004). However, as presented by Klein and Menezes (2004), Vieira da Silva et al. (2016b) and Klein et al. (2010, 2016) when breaker wave height ( $\mathrm{Hb})$ is lower than $0.4 \mathrm{~m}$ it becomes tide-modified. This scenario usually does not occur at the exposed east-facing beaches in the study area but it is common along the protected north-facing area.

\section{Material and Methods}

Dune morphology was mapped using altimetry data derived from 2002 aerial photographs provided by the Urban Planning Institute of Florianópolis. A digital terrain model was also derived from 2010 aerial photographs (altimetric error of about $0.66 \mathrm{~m}$ ), sourced from the Department of Sustainable Development of Santa Catarina State. Field work in the dune field was conducted in 2014 using a GPS in RTK mode, configured to collect data every $0.5 \mathrm{~m}$ along transects spaced $15 \mathrm{~m}$ apart (on 21, 29 and 30/5/2014). Transects, parallel to Ingleses beach, were also measured every $0.5 \mathrm{~m}$ spaced $30 \mathrm{~m}$ apart for whole dunefield on 14/08/2014 (Fig. 1). Since the dune sediment originates on Santinho foredune coast, perpendicular profiles were also measured with same spacing $(30 \mathrm{~m}$, Fig. 1) together with transverse lines on foredune's crest and base. The survey data were interpolated to allow volumetric calculations. Interpolation was undertaken using Inverse Distance Weighting (IDW), which presented the lowest Root Mean Square-RMS (0.08) and best represented the study area compared to other methods. It provided a realistic morphology for 2002, 2010 and 2014. The dunefield volume was calculated above $1.26 \mathrm{~m}$ (mean sea level), so that the whole volume was quantified above the same height. The crest's migration of the dunes were obtained with different satellite images. All data were previously published in Pinto and Klein (2014), Pinto (2015) and Pinto et al (2015).

The nearshore environment was investigated using topographic and bathymetric surveys (Teodolite and Interferometer 4600 Edgetech), sediment transport measurements with Helley-Smith sand traps (Helley and Smith 1971) and three ADCP deployed in the study area. 


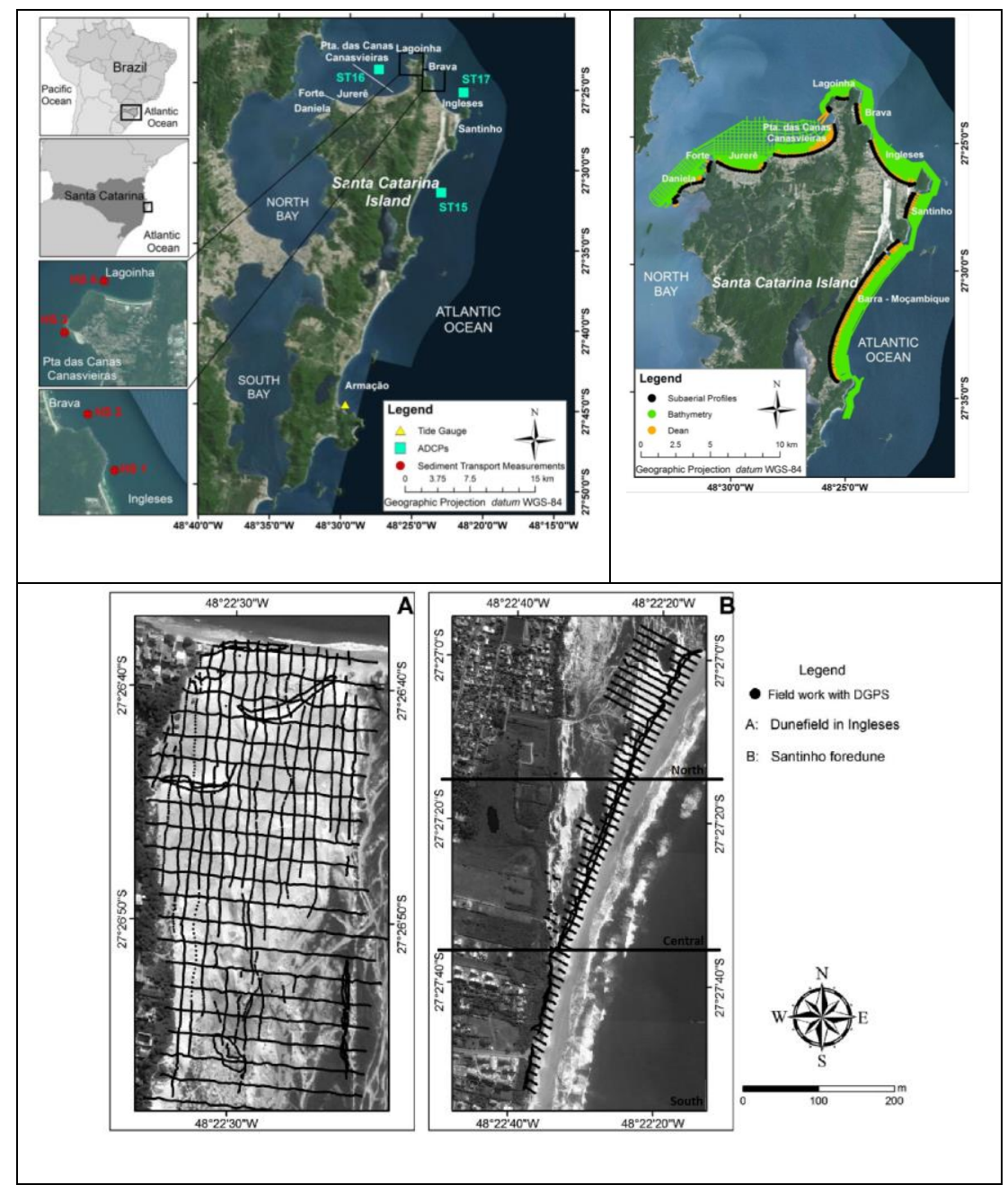

Figure 1 - Top) Location of the study area on the southern of Brazil and morphological details of the beaches in the north area of the Santa Catarina Island. Background image: ESRI Basemap imagery. ESRI World Imagery (ArcGIS 10). Location of measured data for bypassing analysis: STs : ADCP locations; HSs: Helley-Smith trapping locations, bathymetric data. And for overpassing analysis: $A$ and B) topographyc survey with GPS collecting data each $0.5 \mathrm{~m}$ on the dunefield and Santinho foredune.

Vertical photos, satellite images and GIS techniques and a process-based (Deflt3D) numerical model (Fig. 1) were used to evaluate the bypassing process. 
The model set-up and results are the same as presented by Vieira da Silva et al. (2016b, 2018) and included both Wave and Flow modules. The contribution of waves, tides and winds to the headland sand bypassing and overpassing was quantified and the environmental conditions that drive these processes was identified for the study area.

Finally, side scan sonar and seismic data were obtained in front of head lands to define migration direction of ripples and quantify the volume of sedime nt stored in the sandy bodies (Porpilho, 2015, Porpilho et al. 2014, 2015; Martin s, 2017; Martins et al 2017).

\section{Results and discussions}

\section{Overpassing}

The dunefield decreased in volume between 2002-2014. In 2002, the demarcated area covered about $3 \mathrm{Mm}^{3}$. After eight years (in 2010), this decreased to $2,8 \mathrm{Mm}^{3}(7 \%)$ and four years later, in 2014 , the volume was $2,5 \mathrm{Mm}^{3}$, giving an overall $17 \%$ reduction.

The data collected in 2014 with GPS provided a 3D model for the analysis of the sediment input from the dunefield to Ingleses beach. Two dunes within the dune system were evaluated, these dunes stored about $51,000 \mathrm{~m}^{3}$ and $87,000 \mathrm{~m}^{3}$ of sediments; in 2014 their dune crests migrated $16-18 \mathrm{~m} /$ year, which represents sediment input to Ingleses beach was of between $3,000-5,000 \mathrm{~m}^{3} /$ year. These rates were half of rates published by Boeyinga et al. (2010) who calculated that the dunefield contributed around $10,000 \mathrm{~m}^{3} /$ year of sediment to Ingleses. These authors used the length and the angle of the slip face to estimate the sediment volume, whereas this study used a more accurate topographic (GPS) survey method.

The volume that enters in the system through the northern sector of Santinho beach was also calculated. Vieira da Silva et al. (2016) utilizing shoreline change data showed that, when the northern part of Santinho grew, Ingleses retreated. The north sector of the Santinho foredunes (which are more exposed to swell and wind action), have the greatest width and volume, as compared with south sector. Volume changes in the foredune northern sector of Santinho indicate an input to the dunefield approximately $70,000 \mathrm{~m}^{3}$ of sediment 
in 12 years, representing $6,000 \mathrm{~m}^{3} / \mathrm{year}$. At the other end, the dunefield supplies $3,000-5,000 \mathrm{~m}^{3} /$ year of sediment to Ingleses, generating a positive budget indicating the maintenance/growth of the dunefield. As the sediment input is larger than the output to Ingleses, the dune system will continue to provide sediment to Ingleses while growing in overall volume.

Headland bypassing is often associated with cyclic pulses of sediment connected to the overpassing process in the study area (Pinto and Klein 2015, Pinto et al. 2015; Pinto 2015). In 2002 the northern part of Santinho foredune had less volume and area than in 2014, suggesting that a previous pulse of sand had already entered the dune system. In 2010 the foredune volume was higher, suggesting a new pulse was imminent. In 2014, the input was confirmed, by a higher volume in foredune sector north than in previous years (2002, 2010 and $2014,265,000 \mathrm{~m}^{3}, 292,000 \mathrm{~m}^{3}$ and $336,000 \mathrm{~m}^{3}$, respectively). Boeyinga et al. (2010) also noted a sediment pulse in Moçambique dunefield (on the west side of Santinho beach), that occurs every 14 years. Examination of Google Engine satellite images show that sand pulses migrate across (south to north $-700 \mathrm{~m}$ ) the Santinho dunefield with a period around 30 year (since 1984). This means that the rate of dune migration is $23 \mathrm{~m} /$ year that is near the $18 \mathrm{~m} /$ year reported by Pinto (2015), during this time.

\section{Bypassing}

The shoreline change analysis and numerical model results presented by Vieira da Silva (2016a,b) elucidated a complex sediment transport pattern along the north shore of Santa Catarina Island (Fig.2). There is an anticlockwise sediment transport, from ocean beaches to the sheltered areas. The development of Ponta das Canas and Daniela spits for example are dependent on the supply of sediment through bypassing process (Viera da Silva et al 2016a,b; de Camargo et al. 2016, 2017).

Vieira da Silva et al. (2018) showed results of the contribution of tide-, winds- and wave-generated sediment transport to headland bypassing to the study area, as reported by Costa et al. (2019, in this volume) and McCarroll et al (2018) in their studies. Vieira da Silva et al. $(2016 b, 2018)$ results indicate that waves are the main driving force for the headland bypassing as they transport sand at rates two orders of magnitude greater than tide- or wind-driven sediment transport. The tide-driven currents can only transport sediment during spring 
tides in locations where the currents are intensified. It is also demonstrated by the authors that the wave direction plays an important role in sediment transport in the exposed and sheltered areas. In exposed areas with larger headlands a combination of wave directions is required to first transport sediment offshore (out of the beach) and secondly to transport sediment alongshore and back to the next beach, similar to the mechanism proposed by Short and Masselink (1999) and Smith (2001). Whereas in areas with little variation in wave direction and exposure, the same oblique wave direction is responsible for the entire headland bypassing process.

As a result of the hydrodynamic process and sediment transport pathways Vieira da Silva et al (2016b) stated that the development of Daniela spit (the end of north Santa Catarina Island coastal cell) as well as the sediment budget of all updrifit beaches is highly dependent on sand derived from 1) headland bypassing; 2) inner shelf sand that re-enter in the system through Ingleses-Brava and Brava-Lagoinha headlands; and 3) Ingleses dunefield overpassing. The transported sand reaches Lagoinha-Ponta das Canas headland and spit and is continuously transported westward towards Daniela Spit driven by continuously oblique waves.

Vieira da Silva et al (2016b) corroborate Pinto and Klein (2015) findings that the beaches are connected via both headland bypassing and overpassing and through the inner shelf (Fig. 2). On the high energy east-facing beaches the bypassing is entirely subaqueous with rates in the order of $10,000 \mathrm{~m}^{3} \mathrm{year}^{-1}$, with sand also lost and received from the inner shelf below the closure depth $(>7 \mathrm{~m})$. On the lower energy north-facing beaches the rates are on the order of 5,000 $\mathrm{m}^{3} \mathrm{year}^{-1}$, and the transport is also manifested by periodic subaerial spit development and migration in agreement with the conceptual models, with a major terminal spit (Daniela) acting as a sediment sink.

The sand spit of Ponta das Canas Beach, anchored to the Morro de Ponta das Canas rocky headland, develops in the east-west direction and during the study period went through two evolutionary cycles as reported by de Camargo et al. (2016,2017): I) 1938 to 2009; and II) from 2010 to 2018. In cycle 1, the sand spits progressed through different shapes and dimensions, but the gap of images (1938, 1957, 1978, 1994 and 2002) did not allow the measurements to be obtained, and it was not possible to check the timing of sediment bypass cycle accurately. In cycle II, the sand spit started to the develop in 2010 with growth 
and downdrift migration rates of $8,050 \mathrm{~m}^{2} /$ year and $220 \mathrm{~m} /$ year respectively until 2018. Topographic monitoring of the spit showed a growth rate of 29,765 $\mathrm{m}^{2} /$ year, $290 \mathrm{~m} /$ year in its downdrift migration and $20,835 \mathrm{~m}^{3} /$ year in volume (de Camargo et al. 2017).

Vieira da Silva et al. (2016b) demonstrated numerically that sand re-enters in the system from inner shelf, while studies by Porpilho et al (2016) and Martins et al $(2017 \mathrm{a}, \mathrm{b})$ showed that in front of Santinho Headland there is a sink of sediment. The sand body has a volume of almost $48 \mathrm{Mm}^{3}$ (Martins et al 2017a,b), almost 5 times larger than reported by Porpilho et al $(2015)\left(10 \mathrm{Mm}^{3}\right)$. This indicate a longterm accumulation of sediment in front of the headland during Quaternary geological time scale. This area (headlands) works as a sand traffic jam for the sediment transport, in other words, only when the accommodation space is filled with sand, bypassing occurs.

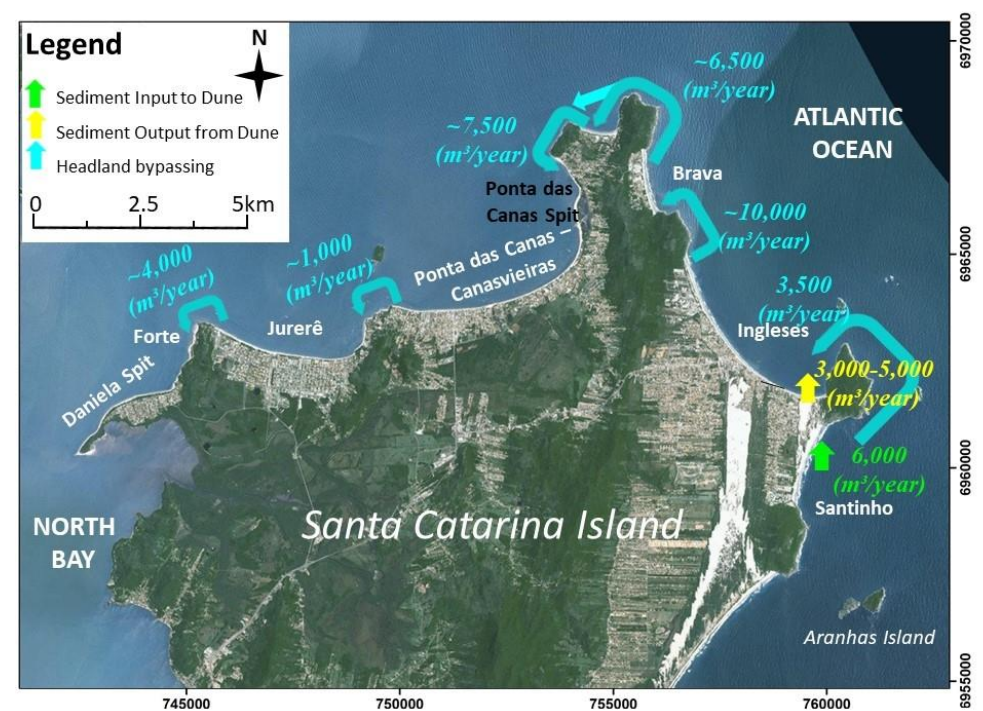

Fig 2. Schematic representation of sediment budget on the northern coast of Santa Catarina Island based in Vieira da Silva et al. (2016b, Pinto et al. 2015, Martins et al. 2017).

\section{Conclusions}

The main outcomes of this paper are: 
- In a historical scale, there is a longshore cyclic supply (pulses) of sand around headlands that form migratory downdrift spits (episodic spit development).

- Aeolian overpassing is driven by a crosshore cyclic supply of sand from the beach to the transgressive dune field to the downwind beach (input of $6,000 \mathrm{~m}^{3} \mathrm{y}^{-1}$ and output of 3,000 to $5,000 \mathrm{~m}^{3} \mathrm{y}^{-1}$ )

- On the inner shelf there is a continuous wave driven sediment bypassing of sediment around headlands at a rate of $4,000 \mathrm{~m}^{3} \mathrm{yr}^{-1}$ to $10,000 \mathrm{~m}^{3} \mathrm{yr}^{-1}$.

- Part of this sand has accumulated in front the Santinho headland forming an inner shelf sand body with a volume $\sim 48 \mathrm{~m}^{3}$ supplied at a rate of 9,000 to $14,000 \mathrm{~m}^{3} \mathrm{yr}^{-1}$ over the last 6,000 years.

Dominant mechanisms for continuous and/or episodic bypassing and overpassing using examples from the north coast of Santa Catarina Island were discussed in this paper. Waves and wind dominate the bypassing and overpassing on exposed east coast of Santa Catarina Island, respectively. Along the more sheltered northern coast swash processes drives longshore transport.

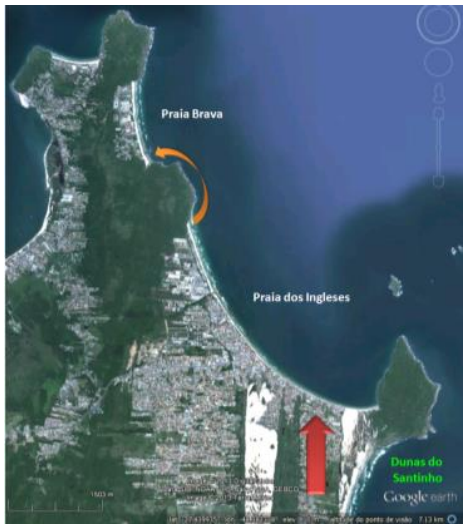

a)

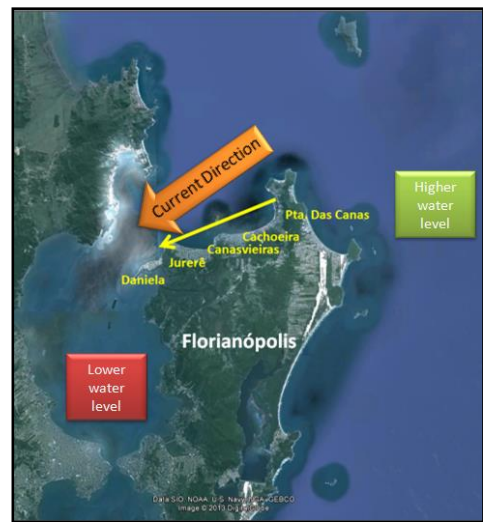

b)

Fig 3. Schematic representation of bypassing and overpassing by wave and wind on the northern coast of Santa Catarina Island (a), and in protected areas by tidal currents and swash processes (b) (modified from Vieira da Silva et al., 2016 and 2018; Pinto, in preparation). 


\section{Acknowledgements}

The authors would like to acknowledge the support of Fundo Clima MMA (Process number 3520120), CNPQ (Process number 400302/2012-8 and 303550/2012-0), PRH-PB240 (Process number 48610.002443/2013-14), CAPES (Process number: 005809/2014-02), CASAN and SL\&I, INCT MAR COI - CNPQ (Process numbers 400551/2014-4). This paper is a contribution of the Brazilian Research Network on Global Climate Change FINEP/ Rede CLIMA Grant 01.13.0353-00

\section{References}

Angulo, R. J., Lessa, G. C., and de Souza, M. C. (2006). "A critical review of mid-to late-Holocene sea-level fluctuations on the eastern Brazilian coastline," Quaternary Science Reviews, 25, 486-506.

Ab Razak, M. (2015). Natural headland sand bypassing. Towards identifying and modelling the mechanisms and processes. PhD Thesis, Delft University of Technology. CRC Press/Balkema, Netherlands, 187 p.

Boeyinga, J., Dusseljee, D.W., Pool, A.D., Schoutens, P., Verduin, F., Van Zwicht, B.N.M., and Klein, A.H.F. (2010). The effects of bypass dunefields on the stability of a headland bay beach: A case study. Coastal Engineering,57, 152-159.

Cooper, J.A.G., Green, A.N., Meireles, R.P., Klein, A.H.F., Souza, J. and Toldo, E.E. (2016). Sandy barrier overstepping and preservation linked to rapid sea level rise and geological setting. Marine Geology, 382, 80-91.

Cooper, J.A.G., Meireles, R.P., Green, A.N., Klein, A.H.F. and Toldo, E.E. (2018). Late Quaternary stratigraphic evolution of the inner continental shelf in response to sea-level change, Santa Catarina, Brazil. Marine Geology, 397, 1-14.

Davies, J.L. (1974). The coastal sediment compartment. Aust. Geogr. Stud. 12, 139-151

de Camargo, J.M., Klein, A.H.F. and Short, A.D. (2016). Spit evolution as a 
result of headland bypassing. International Coastal Symposium Abstracts, Crowne Plaza Coogee Beach, Sydney, Australia.

de Camargo, J.M., Costa, W. L., Martins, M. S., Bittencourt, A. C., Klein, A. H. F. and Silveira, L. (2017). Evolução morfodinâmica do Pontal do Capri e Praia do Forte, Ilha de São Francisco do Sul, SC. Anais do Congresso. ABEQUA.

Duarte, J., Taborda, R., Ribeiro, M., Cascalho, J., Silva, A. and Bosnic, I. (2014). Evidences of sediment bypassing Nazaré headland revealed by a large scale sand at tracer experiment. Actas das 3as Jornadas de Engenharia Hidrográfica. Instituto Hidrográfico, Lisbon, pp.289-292.

Evans, O.F. (1943). The relation of the action of waves and currents on headlands to the control of shore erosion by groins. Proceedings of the Oklahoma Academy of Science, 24: 9-13.

George, D. A., Largier, J. L., Storlazzi, C. D. and Barnard, P. L. (2015). Classification of rocky headlands in California with relevance to littoral cell boundary delineation. Marine Geology, 369, 137-152.

Goodwin, I. D., Freeman, R., and and Blackmore, K. (2013). An insight into headland sand bypassing and wave climate variability from shoreface bathymetric change at Byron Bay, New South Wales, Australia. Marine Geology, 341, 29-45.

Hein, C. J., FitzGerald, D. M., Cleary, W. J., Albernaz, M. B. , Menezes, J. T. and Klein, A.H.F. (2013). Evidence for a transgressive barrier within a regressive strandplain system: Implications for complex coastal response to environmental change. Sedimentology, 59, 1-34.

Hein, C. J., FitzGerald, D.M., Menezes, J.T., Cleary, W.J., Klein, A.H.F. and Albernaz, M. B. (2014). Coastal response to late-stage transgression and sea-level highstand. Geological Society of America Bulletin, 1B, 308 -36.1

Hein, C. J., Georgiou, I. Y., FitzGerald, D. M., Souza, L. H., Klein, A. H., and Menezes, J. T. (2015). "Wave energy, sediment supply, and sea-level fall: Late Holocene basin infilling in southern Brazil." Proceedings of Coastal 
Sediments 2015. World Scientific, 16 p.

Hein, C. J., Shawler, J. L., de Camargo, J.M., Klein, A.H.F., Tenebruso, C., Fenster, M. S. (2019, this volume). The role of coastal sediment sinks in modifying longshore sand fluxes: examples from the coasts of southern Brazil and the mid-atlantic USA. Proceedings of Coastal Sediments 2015. World Scientific, p.

Klein, A. H. F. and Menezes, J. T. (2001). Beach morphodynamics and profile sequence for a headland bay coast. Journal of Coastal Research, 17, 4, $812-835$

Klein, A.H.F., Short, A. D. and Bonetti, J. (2016). Santa Catarina Beach Systems. In: AD Short, AHF Klein. (Org.). Brazilian Beach Systems. 1ed. Switzerland: Springer International Publishing Switzerland, 465-506.

Klein, A.H.F., Ferreira, Ó., Dias, J. M.A., Tessler, M.G., Silveira, L.F., Benedet, L., Menezes, J.T. and Abreu, J.G.N. (2009). Morphodynamics of structurally controlled headland-bay beaches in southeastern Brazil: A review. Coastal Engineering, 57, 98-111.

Martins, M. S. (2017). Mapeamento geoacústico da reserva de areia na área marinha adjacente a ponta dos Ingleses, Em Florianópolis, Santa Catarina.. 2017. Trabalho de Conclusão de Curso. (Graduação em Oceanografia) Universidade Federal de Santa Catarina. 70p

Martins, M. S., Klein, A.H.F., Meireles, R. P., Demarco, L.F.W. and Souza, L. A. P. (2017). Use of Continuous Seismic Profiling and Side Scan Sonar for Identification and Characterization of Sand Banks. In: Rio Acoustics 2017, 2017, Rio de Janeiro. 2017 IEEE/OES Acoustics in Underwater Geosciences Symposium (RIO Acoustics), p. 1-5.

Martin, A.K and Flemming, B.W. 1986. The Holocene shelf sediment wedge off the south and east coast of South Africa. In: Knight, R.J. and McLean, J.R. (eds), Shelf sands and sandstones. Canadian Society of Petroleum Geoloigists Memmoir II, 27-44.

McCarroll, R., Masselink, G., Valiente, N., Scott, T., King, E. and Conley, D. 
(2018). Wave and Tidal Controls on Embayment Circulation and Headland Bypassing for an Exposed, Macrotidal Site. Journal of Marine Science and Engineering, 6(3), 94; doi:10.3390/jmse6030094

McLachlan, A., Illenberger, W.K., Burkinshaw, J.R. and Burns, M.E.R. (1994). Management implications of tampering with littoral sand sources. Journal of Coastal Research, SI 12, 51-59.

Pinto, M.W. (2015). Evolução morfodinâmica em escala histórica do campo de dunas do Santinho-Ingleses no norte da ilha de Santa Catarina. Master's thesis. Universidade Federal de Santa Catarina. Florianópolis. 120p.

Pinto, M. W. and Klein, A.H.F. (2014). The evolution of vegetation cover and its effects on the stabilization of a transgressive dune field in the Santinho/Ingleses system, Santa Catarina island, Brazil. Journées EUCCFrance et Coastal \& Marine Union (EUCC),p1.

Pinto, M. W., Meireles, R. P., Cooper, J. A. G. and Klein, A.H.F. (2015). Santinho/Ingleses Transgressive Dunefield System - Santa Catarina Island (Brazil): Temporal Variability in Vegetation, Manmade Structures and Dune Migration. Proceedings Coastal Sediments 2015. World Scientific,1, $1-14$.

Porpilho D. (2015). Padrão morfológico e sonográfico da plataforma continental interna adjacente ao setor Leste da Ilha de Santa Catarina. Dissertação (Mestrado em Geografia) - Universidade Federal de Santa Catarina 130p.

Porpilho, D., Klein, A.H.F., Camargo, R.S.V., Prado, M.F.V., Bonetti, J., Short, A. D. and Fakiris, E. (2014). Automatic classification of bedforms using phase differencing bathymetric sonar. Underwater Acoustics 2014, p. 1-6.

Porpilho, D., Klein, A.H.F., Camargo, R.S.V., Prado, M.F.V., Short, A. D., Vieira da Silva, G. and Toldo, E.E. (2015). Bedform Classification in Front of Santinho Headland, Santinho Beach, Santa Catarina Island, Brazil. Proceedings Coastal Sediments 2015., 1, 1-10.

Porpilho, D., Klein, A.H.F., Camargo, R.S.V., Prado, M.F.V., Short, A. D. and Vieira da Silva, G. (2016). Headland bedform characterization through 
interferometric data, Ingleses, Santa Catarina Island, Southern Brazil. In: IX PIANC-COPEDEC, 2016, Rio de Janeiro, p. 1-7.

Roy, P.S., Cowell, P.J., Ferland, M.A. and Thom, B.G. (1999). Wave-dominated coasts. In: Carter, R.W.G. and Woodroffe, C.D. (1999). Coatal Evolution Late Quaternary shoreline morphodynamics. Cambridge University Press. p. $121-186$

Ribeiro, M.S.A (2017). Headland sediment bypassing processes. Tese de Doutorado. Universidade de Lisboa. Lisboa, Portugal. 210 p.

Ribeiro, M., Taborda, R., Lira, C., Bizarro, A. and Oliveira, A. (2014). Headland sediment bypassing and beach rotation in a rocky coast: an example at the western Portuguese coast. Geophys. Res. Abstr. 16 (EGU2014-14602).

Thom, B.G., Eliot, I., Eliot, M, Harvey, N., Rissik, D., Sharples, C., Short, A.D. and Woodroffe, C.D. (2018). National sediment compartment framework for Australian coastal management. Ocean and Coastal Management,154:103-120

Tinley, K.L. (1985). Coastal dunes of South Africa. South African National Scientific Programmes Report No. 109. 300p.

Vieira da Silva, G., Muler, M., Prado, M. F. V., Short, A. D., Toldo Jr., E. E., Klein, A. H. F., 2016a, Shoreline changes analysis and insights into sediment transport path - example of Santa Catarina Island North Shore, Brazil. Journal of Coastal Research. 32(4), 863-874.

Vieira da Silva, G, Toldo Jr.,E.E., Klein, A.H.F., Short,A.D., Woodroffe,C.D., 2016b. Headland sand bypassing - quantification of net sediment transport in embayed beaches, Santa Catarina Island North Shore, Southern Brazil. Marine Geology. 379, 13-27.

Vieira da Silva, G, Toldo Jr.,E.E., Klein, A.H.F., Short,A.D. 2018. The Influence of Wave-, Wind- and Tide-Forced Currents on Headland Sand Bypassing Study Case: Santa Catarina Island North Shore, Brazil. Geomorphology, 312, 1-11. 
Short, A.D. and Masselink, G. (1999). Embayed and structurally controlled beaches. In: Short, A.D. (editor). Handbook of beach and shoreface morphodynamics. Wiley and Sons, Chichester, p230-249.

Smith, A.W. (2001). Headland bypassing. Coasts \& Ports 2001: Proceedings of the 15th Australasian Coastal and Ocean Engineering Conference, the 8th Australasian Port and Harbour Conference. Institution of Engineers, Australia, Barton, A.C.T., p. 214-216. 